\title{
Comments
}

\section{INSPECTION OF PUBLIC RECORDS UNDER CALIFORNIA LAW}

It is the policy of the State of California that public records and documents be open for public inspection in order to prevent secrecy in governmental affairs....1

Few would quarrel with this statement of legislative policy. Openness in the conduct of public affairs and an informed citizenry are undeniably necessary to a society founded on democratic principles, and therefore it is to be expected that there be a general right of inspection of records. However, it is neither desirable nor practical to make all records, documents, and writings possessed by the government available to the public. In some cases, particularly where communications are made in confidence to officials, the public interest may require secrecy. Moreover, private individuals must, under regulatory and taxation laws, provide the government with information concerning their private affairs. Their privacy should be protected by making such data available only to officials administering the laws. In addition, an assurance of privacy generally serves the public interest by promoting full disclosure. The purpose of this Comment is to investigate the statutes and cases establishing and limiting the right of inspection in California.

\section{THE GENERAL INSPECTION STATUTES}

The two general sources of the right to inspect public records are section 1892 of the Code of Civil Procedure and section 1227 of the Government Code. The first relates to "public writings"; the latter to "public records and other matters."

Section 1892 of the Code of Civil Procedure provides: "Every citizen has a right to inspect and take a copy of any public reriting of this State, except as otherwise expressly provided by statute."2 The California courts determined early that if a record is required to be kept, either by a statute or by some other proper authority, such as an administrative regulation, it is a public record..$^{3}$ Therefore such a writing is open to inspection in the absence of an express statute or requirement of the public interest to the contrary. ${ }^{4}$ In addition, the courts have con-

1 A. Jt. Res. 9, Cal. Leg., Reg. (Gen.) Sess., Cal. Stats. ch. 111, p. 5588 (1959).

2 Emphasis added.

3 See Kyburg v. Perkins, 6 Cal. 674 (1856); Walker v. Superior Court, 155 Cal. App. 2d 134, 139, 317 P.2d 130, 133 (1957). These cases dealt only with records kept by government officials.

4 Where there is a question concerning the status of a particular writing and the official in charge refuses to allow inspection, his decision may be reviewed by seeking a writ of inandamus under CaL. CoDE Crv. Proc. $\$ \$ 1085$, 1086. Under the common law, the writ could be issued ordering inspection only if the petitioner could show some special or beneficial interest in the records beyond his general right as a citizen. The California courts, however, have held that the inspection statutes have liberalized the former rule. The early case of Colnon $v$. Orr, 71 Cal. 43, 11 Pac. 814 (1886), denied the writ to a citizen where it did not appear that he had any special interest in the records. However, other grounds for denial of the writ were present, since the records sought were confidential communications. The court in Harrison v. Powers, $19 \mathrm{Cal}$. App. 762, $127 \mathrm{Pac} .818$ (1912) distinguished Colnon because the petitioner in Harrison sought the writ in order to further his lawful business. In Mushet v. Department of Public Service, 35 Cal. App. 630, 170 Pac. 653 (1917), the court seemed to have assumed that the right of the citizen to inspect under the statute was in itself a sufficient interest. And Coldwell v. Board of Public Works, 187 Cal. 510, 202 Pac, 879 (1921), established that the interest of a citizen was enough to obtain the writ. 
sistently said that public records also include writings that are merely necessary or convenient to the discharge of an official's duties. ${ }^{5}$ Two other code sections establish more precisely what is included in the term "public writing."

The first of these, section 1888 of the Code of Civil Procedure, defines public writings as:

1. The written acts or records of the acts of the sovereign authority, of official bodies and tribunals, and of public officers, legislative, judicial, and executive, whether of this State, of the United States, of a sister State, or of a foreign country;

2. Public records, kept in this State, of private writings.

The second, section 1894 of the Code of Civil Procedure, divides public writings into four classes: "1. Laws; 2. Judicial records; 3. Other official documents; 4. Public records, kept in this State, of private writings."

The case of Mushet v. Department of Public Service ${ }^{\mathfrak{b}}$ established that for a document to be a public writing it must conform to both sections 1888 and 1894 . Thus subdivision 2 of section 1888 corresponds with subdivision 4 of 1894. And in order for a writing to belong to one of the classes enumerated in subdivisions 1,2 , and 3 of 1894 , it must fall within the definition of $1888(1){ }^{7}$

It has generally been agreed that the language of subdivisions 2 of section 1888 and 4 of section 1894, viz., "public records . . . of private writings," is narrow in meaning, and refers to documents filed by citizens pursuant to the various recording laws. ${ }^{8}$ Subdivisions 1 and 2 of section 1894 should also create no problems, since it should be clear whether a writing is a law or a judicial record. Difficulties arise, however, in determining whether writings are in the class of "other official documents" and are also "written acts or records of the acts" of a public body or officer. The courts and the California Attorney General's office have spent considerable time in attempting to distinguish adequately between writings that are written acts or records of acts and those that are not. ${ }^{0}$ In one case, for example, the California Supreme Court held that plans for public projects were written acts only when finally approved by the official in charge. Prior to such action they were merely the prehminary bases for an act and therefore did not come within section $188 .^{10}$

5 People v. Shaw, 17 Cal. 2d 778, 811, 112 P.2d 241, 258-59 (1941); People v. Tomalty, 14 Cal. App. 224, 231, 111 Pac. 513, 516 (1910).

635 Cal. App. 630, 170 Pac. 653 (1917).

7 Id. at 634,170 Pac. at 655 .

8 See, e.g., 13 Ors. Cax. Atr'y Gen. 180, 181 (1949); 11 Ops. Car. Att'y Gen. 41, 44 (1948). Possible support for the conclusion that the coverage of these subdivisions is so restricted may be found in D. I. Nofziger Lumber Co. v. Solomon, 13 Cal. App. 621, 626-27, 110 Pac. 474, 476 (1910).

${ }^{9}$ See, e.g., 13 Ops. CaL. ATT'Y Gen. 180 (1949).

10 Coldwell v. Board of Public Works, 187 Cal. 510, 519-20, 202 Pac. 879, 882-83 (1921). In that case, however, inspection was permitted on other grounds. See text at note 14 infra.

Examples of written acts include: rules, orders, and regulations promulgated by agencies; final plans on which action is to be taken; and records or reports required to be made by law. In general, it may be said that a written act requires a quality of finality and officiality that plans or memoranda would not have. Examples of records of acts are reports, made by public officers of their activities, and journals and minutes of meetings of official bodies.

On the other hand, records, forms, documents, correspondence, and other communications made by private citizens are not acts or records of acts of public officers. It must be noted, however, that certain writings filed by private citizens (in addition to those covered by the recording statutes) are made public records by specific statutes. E.g., CAL. CORP. CODE $§ 25314$ opens to inspection certain papers, documents, reports, and other written instruments filed with the Commissioner of Corporations. See also Cat. Corp. CODE \$ 27005 ; CaI. FIN. Code $\$ 17417$; CAL. INS. CODE $\$ 855$. 
However, too much emplrasis may be placed on the test, established by the Mushet case, requiring compliance with the language of both sections 1888 and 1894. The courts, relying on section 1227 of the Government Code, have made it clear that merely because a writing does not fall within the specific definitions of public writings does not mean that it is to be kept from the public. Section 1227, the second general source of the right to inspect, states that: "The public records and other matters in the office of any officer, except as otherwise provided, are at all times during office hours open to inspection of any citizen of the State." While the term "public records" lias been equated with "public writings" as used in section 1888,12 the broad language providing that "other matters" are open to inspection has been used to extend inspection generally to writings relating in some way to public affairs. Indeed, the two leading cases, Mushet and Coldwell v. Board of Public Works, ${ }^{13}$ after elaborately setting up the public writings test, allowed inspection even though in neither case did the documents in question fit the defimitions.

In Coldwell the petitioner sought inspection of preliminary data and reports on which the final reports and recommendations of the city engineer for the San Francisco water procurement project were based. The court found imitially that the writings did not fall within the specific definitions of public writings and hence were not public records. Nevertheless, the court did lold that they were "other matters" within the neaning of section 1227. Their connection with a great public utilities project caused them to be of legitimate public interest. Therefore, inspection was granted.14

In view of the Coldwell result, it is evident that a mecharical test for determining whether a record is public is not adequate. Instead, in every case the more fundamental question must be asked-whether the document in question is one in which the public has a legitimate interest. Does it deal with the manner in which the public business is being or has been conducted, or will it provide information on matters concerming the public welfare? If so, then inspection slould be allowed in the absence of an overriding contrary public interest. ${ }^{15}$

From these principles the courts early developed a limitation to the term "other inatters" that removed some writings found in public offices from the scope of the inspection statutes. In effect, section 1227 has been construed as referring to "other public matters." "Public" lias been defined as "of, pertaining to, or affecting, the people at large or the commumity." "16 The definition, there-

11 Emphasis added.

${ }^{12}$ See Coldwell v. Board of Public Works, 187 Cal. 510, 518, 202 Pac. 879, 882 (1921).

13187 Cal. 510, 202 Pac. 879 (1921); Note, 10 CarIF. L. Rev. 346 (1921).

14187 Cal. at 520, $202 \mathrm{Pac}$. at 883. In the Mushet case the records involved were those of the Los Angeles Department of Public Service. After setting up the test, the court decided that the documents were not official or public writings because they related to a "private business" carried on by the city. $35 \mathrm{Cal}$. App. at 634-35, $170 \mathrm{Pac}$. at $655-56$. Why this fact should have made the records any less public was not made clear. (But cf. New York Post Corp. v. Moses, 10 N.Y.2d 199, 176 N.E.2d 709, 219 N.Y.S.2d 7 (1961), which seems to give support to the Mushet court on this point.) However, the court allowed inspection by drawing an analogy to a private corporation. Thus, it was held that the taxpayers had the same rights of inspection as stockholders have over the records of their company. It is not at all apparent why the court chose this indirect route in allowing inspection. The later cases have disregarded this aspect of the case.

15 For an enumciation of the basic considerations, see Egan v. Board of Water Supply, 205 N.Y. 147, 98 N.E. 467 (1912).

18 Coldwell v. Board of Public Works, 187 Cal. 510, 520, 202 Pac. 879, 883 (1921). 
fore, does not include records that reveal only the private affairs of citizens. Thus, under the general inspection statutes such records may be kept confidential. As will be seen, the conclusion that the correct guide in construing the general inspection statutes is the distinction between public and private is reinforced by the fact that most of the records withdrawn from inspection by specific statutes have to do with private affairs.

II

\section{SPECIFIC STATUTORY TREATMENT OF THE RIGHT TO INSPECT}

In both the general inspection statutes and in many of the statutes referring to specific agencies, inspection is required "except as otherwise provided for by law." Scattered throughout the California codes are a great number of statutes covering particular documents, specific agencies, or certain kinds of records. ${ }^{17}$ Although it would be impractical here to discuss all of these provisions individually, it is possible to draw a few general conclusions that may serve as a guide in the application of any particular section.

As mentioned above, the great majority of the provisions remove from inspection records that reveal information concerning the private affairs of individuals required for the administration of various regulatory and taxation laws. ${ }^{18}$ The sections fall into a number of categories. First, there are sections that prohibit disclosure of specific records except in the performance of official duties to which they relate. Generally under such laws the official in charge of the records may not waive the prohibition of the act and allow inspection. The most typical example of records thus protected are personal income tax returns. ${ }^{10}$ Tlie purposes of the statute in this instance are apparently to protect privacy and to encourage full disclosure by taxpayers. Similarly, records of the welfare department are required to be held in confidence. ${ }^{20}$ The justification for this statute is presumably to prevent embarassment to recipients of aid. Secondly, there are statutes prohibiting the disclosure (with exceptions) of certain kinds of information, usually that obtained from an examination of private records during an investigation. ${ }^{21}$ Thirdly, a number of statutes give officials discretion to determine the extent to which inspection of certain kinds of records may be permitted. Generally, such provisions allow inspection unless the official believes it would be contrary to the welfare of the public or of the private party supplying the information. ${ }^{22}$ The broad grant of discretion probably means that the official's determination will be considered final by the courts, unless perhaps there has been an obvious abuse of discretion.

17 Altogether, there are more than 200 provisions in the California codes dealing in one way or another with records in public offices.

18 There are approximately eighty-eight sections or groups of sections probibiting or restricting disclosure of certain records. Of these, seventy-eight deal with reeords relating primarily to the private and business affairs of individuals and corporations.

19 CAI. REv. \& TAX. CoDE $\$ \S 19282-89$. Under California law the taxpayer may prevent inspection of his own copy of the tax return. Webb v. Standard Oil Co. of California, $49 \mathrm{Cal}$. 2d 509, 319 P.2d 621 (1957), distinguishing, Samish v. Supreme Court, 28 Cal. App. 2d 685, 83 P.2d 305 (1938). The federal rule seems to be the opposite, see St. Regis Paper Co. v. United States, 368 U.S. 208 (1961), rehearing denied, 368 U.S. 972 (1962).

20 CAL. WeLfare \& InsT'NS CODE $\$ \$ 118,2506$.

21 E.g., CaL. Gov't Code $\S 11183$.

22 E.g., Cat. Corp. Code $\S \S 25314,27005$; Cax. Frn. Code $\S 17417$; CaL. INs. Code $\$ 855$. 
In accordance with the dominant policy of allowing inspection, the courts lave generally construed strictly the statutes requiring certain records to be kept secret. Thus, when a statute makes it clear that a specific document is involved, disclosure of related writings not within the express terms of the provision will be permitted. For example, sections 20012 and 20013 of the Vehicle Code provide that reports required to be made by those involved in certain accidents are for the confidential use of the Department of Motor Vehicles and will not be admissible in evidence. The courts have, however, allowed officers to testify to statements and informal reports made to them. ${ }^{23}$

Despite the general inspection statutes, the statutes dealing with specific records, and the rules that the courts have developed in their application, considerable confusion often existed in the practices of various agencies. In 1953 the Senate Special Committee on Governmental Administration conducted an inquiry into the policies followed by the various state agencies in granting or denying inspection of their records. The investigation revealed that there was considerable uncertainty on the part of administrators as to what records were properly confidential. Many agencies had removed records from inspection whose proper status was doubtful. 24

In 1957, 1959, and 1961 the legislature passed a series of statutes affecting more than seventy state boards, commissions, and departments. ${ }^{25}$ The statutes took one of two forms: either they read, "All records of the board [commission, etc.] shall be open to inspection by the public during regular office hours"; ${ }^{28}$ or to that clause was added, "except as otherwise provided by law."27 The first group of statutes made all the records of the agencies involved public. The legis-

23 Dwelly v. McReynolds, 6 Cal. 2d 128, 131, 56 P.2d 1232, 1234 (1936); Carroll v. Beavers, 126 Cal. App. 2d 828, 273 P.2d 56 (1954). There are apparently two reasons for not allowing the reports to be used in evidence. First, they may be incriminatory, and therefore a person could refuse to sign them if they were competent to be received in evidence. And secondly, the necessity for the department to acquire adequate and accurate information relating to the causes of accidents requires that the reports be madmissible in order to encourage full disclosure. For a discussion of such exclusionary statutes, see McCormick, EvmenCE 311-12 (1954).

24 Cal. Senate Special Committee on Governmental Administration, Public Records Survey, 1 Appendix to the Journax of the Senate 9, Cal. Leg., Reg. (Gen.) Sess. (1955). This report provides considerable information concerning the actual practice of state agencies. It is, however, somewhat out of date because of the recent enactments discussed in the text at notes 26 to 28 infra. For a discussion of the problems of government secrecy in both the federal and California governments, see Pickerell, Secrecy and the Access to Administrative Records, 44 CALIF. L. REV. 305 (1956).

25 It is not clear whether these statutes were passed in direct response to the results of the survey of 1953.

28 E.g., CAX. Gov'T CoDE $\S \S 13913$ (State Board of Control); 15487 (Board of Investment); CAI. LABOR CODE $\$ 3092$ (Apprenticeship Council). Forty-seven agencies are thus covered to date.

27 E.g., CAI. Bus. \& Prof. Code $\$ \S 2122$ (Board of Medical Examiners); 4013 (State Board of Pharmacy) ; 9536 (State Board of Dry Cleaners) ; CAL. Gov'T CoDE \& 20137 (Board of Administration, State Employees' Retirement System). A total of twenty-five agencies have been covered by such provisions. At the same time that the sections dealing with records were passed, the legislature enacted provisions governing the conduct of the meetings of the agencies. All meetings of the agencies covered by the first group of statutes must be open to the public, e.g., Cax. Gov'T CoDE $\$ 13912$ (Board of Control). The agencies in the second group, on the other hand, may hold closed meetings for certain specified purposes, generally the consideration of examinations and the discussion of personnel inatters, e.g., CaL. Bus. \& PROF. CODE $\$ 2121$ (Board of Medical Examiners). 
lature has, in effect, decided that none of the documents in the agencies' possession should be treated as confidential. ${ }^{28}$ The second group also makes all records public, but provides for exceptions. Thus, under the exceptions, records that are made confidential by specific statutes or that fall within the category of confidential communications to a government official are not open to inspection. ${ }^{20}$ Although the courts have not yet interpreted these provisions, their unequivocal language leaves little doubt about the status of the records of the agencies involved.

\section{III}

\section{RESTRICTIONS ON THE RIGHT TO INSPECT-GOVERNMENNTAI PRIVILEGE}

In addition to the records covered by specific code provisions, writings may be closed to public inspection because the public interest in their being kept confidential overrides that of inspection. Subdivision 5 of section 1881 of the Code of Civil Procedure provides: "A public officer cannot be examined as to communications unade to him in official confidence, when the public interest would suffer by the disclosure." The courts have held that certain records are privileged under this statute and therefore are not open to inspection.

On the basis of the California cases, a number of rules concerning governmental privilege may be stated. First, there must be a commumication made to the officer in confidence. Secondly, since the privilege is for the benefit of the state and not the person making the commumication, ${ }^{30}$ the public interest, rather than that of the informer or officer, unust be endangered by disclosure. ${ }^{31}$ Finally, although the officer must make the initial decision whether a communication should come within the official privilege, the courts will make the final determination..$^{32}$ However, the courts have generally upheld claims of privilege in cases where only a possibility of injury to the public interest has been shown, and lave not required that it be demonstrated that such injury would in fact occur. ${ }^{33}$

Most of the California cases arising under section 1881(5) have involved information secured from an informant and the disclosure of either the record or the identity of the informant would make it difficult for the government to secure similar information in the future. In such cases, there has been a communication made with the understanding that it would be held in confidence. The public interest to be protected is that of the government being able to acquire information necessary for the efficient conduct of the public's affairs.

When the question of governmental privilege arises in cases involving an at-

28 It is possible that conflicts may arise between these sections and other provisions that permit confidentiality. For example, an agency may receive written advice from an attorney that would normally fall within the attorney-client privilege. Whether a court would permit such communications to be kept secret despite the all-inclusive language of the new sections is problematical.

20 For example, Car. Bus. \& Prof. Cone $\$ 9632$ provides that all records of the Cemetery Board shall be open except as otherwise provided by law. Car. Bus. \& Pror. CoDE $\$ 9650.3$ requires that reports by cemeteries of endownent funcls shall not be open to inspection.

30 Markwell v. Sykes, 173 Cal. App. 2d 642, 647-48, 343 P.2d 769, 772-73 (1959).

31 People v. Denne, 141 Cal. App. 2d 499, 512, 297 P.2d 451, 459 (1956). In criminal cases, the state often asserts the privilege in order to protect the life of an informer. In the instance of public records, of course, this consideration would not arise.

32 Markwell v. Sykes, 173 Cal. App. 2d at 647, 343 P.2d at 772.

33 See, e.g., City \& County of San Francisco v. Superior Court, 38 Cal. 2d 156, 238 P.2d 581 (1951). 
tempted inspection of records in public offices, the courts have generally been willing to accept the official's contention that the public interest may suffer. This policy may be contrasted with that adopted in crimmal cases when the government seeks to keep the identity of informers secret, both to maintain its sources of information and to protect the informers themselves. Since the state, as prosecutor, seeks to conceal the identity of a witness of possible value to the defendant, the courts have applied section 1881(5) more strictly, and have required either disclosure in order to ensure fairness or dismissal of the case. ${ }^{34}$

The case of City \& County of San Francisco v. Superior Court ${ }^{35}$ illustrates the application of section 1881(5). In a suit brought by employees of the city, the trial court ordered the defendant city to produce data it had collected from private employers in an investigation of pay rates. The city claimed that when the information was solicited it was promised that the source would be held in confidence. Without this promise, the city testified, it would be impossible to obtain the voluntary cooperation of the private employers. ${ }^{36}$ The California Supreme Court reversed the order and held that the records were privileged under section 1881(5) and therefore not open to public inspection. Since, the court said, the keeping of faith with confidential informants is an indispensable condition of future efficient and effective governmental action, the public interest in maintaining sources of information would outweigh the immediate interest of an individual in acquiring the particular records. ${ }^{37}$ Moreover, the court found an additional public interest in nondisclosure of the particular documents because of the possibility of public unrest and disruption of labor-management relations if the information was revealed. ${ }^{38}$

It does not necessarily follow from these cases, however, that all communications from private parties will be closed to inspection. The state itself must promise that they will be kept in confidence. Moreover, if there is no public interest to be served by secrecy and the communication in question casts light on the conduct of public business, inspection will be appropriate. ${ }^{39}$

One of the problems in the consideration of any privilege is whether a com-

34 People v. McShann, 50 Cal. 2d 802, 808, 330 P.2d 33, 36 (1958). For a contrast between the courts' attitude in criminal cases and in inspection cases, compare People v. Kiihoa, $53 \mathrm{Cal}$. 2d 748, 349 P.2d 673, 3 Cal. Rptr. 1 (1960), with City \& County of San Francisco v. Superior Court, 38 Cal. 2d 156, 238 P.2d 581 (1951). A distinction between the two situations seems justified. Where a party is merely seeking to inspect records, there will generally not be present an interest as important as protecting the rights of a defendant in a criminal proceeding. For the federal treatment of the problem of the mformer in a criminal proceeding, see Roviaro v. United States, 353 U.S. 53 (1957).

$3538 \mathrm{Cal} .2 \mathrm{~d} 156,238$ P.2d 581 (1951).

$3638 \mathrm{Cal} .2 \mathrm{~d}$ at 159,238 P.2d at 583.

3738 Cal. $2 \mathrm{~d}$ at 163,238 P.2d at 585 .

3838 Cal. 2d at 159, 238 P.2d at 583. Two more examples demonstrate the general consistency with which the courts have applied these principles. In Runyon v. Board of Prison Terms \& Paroles, 26 Cal. App. 2d 183, 79 P.2d 101 (1938), the court denied inspection of letters and other private commumications and documents sent to the parole board on the ground that information needed to discharge the board's duties could be acquired only by assuring confidentiality. And Chronicle Publishing Co. v. Superior Court, 54 Cal. 2d 548, 354 P.2d 637, 7 Cal. Rptr. 109 (1960) held that the defendant in a libel suit could not force disclosure by the state bar of complaints (and complainants' naines) regarding the plaintiff's professional conduct. The communications were made in confidence, and the public interest in the bar receiving all complaints against attorneys required the protection of informers from possible libel suits.

${ }^{38}$ Cf. Egan v. Board of Water Supply, 205 N.X. 147, 157, 98 N.E. 467, 470 (1912). 
munication protected from compulsory disclosure may be revealed by the person to whom it was made. More specifically, when may an official who holds a writing privileged under section 1881(5) release it for public inspection? May he do so unilaterally, or must he obtain the consent of the person making the communication? Since the privilege is expressly to serve the public interest, it is for the benefit of the state, the recipient of a communication, and not the communicant. ${ }^{40}$ This is unlike other privileges, such as the attorney-client privilege, which are for the benefit of the maker of the communication. Thus, the informant cannot place the communication within the privilege himself by insisting that it be kept confidential. ${ }^{41}$ It is for the state to raise the privilege, and if it does not choose to do so, neither may another party. ${ }^{42}$ Therefore, it would follow that it is within the power of the state to waive the privilege, and it is not necessary to obtain the consent of the informant. ${ }^{43}$ Ordinarily then, it is up to the official in charge of the office where the documents in question are located to decide whether it is appropriate to interpose the privilege in order to prevent inspection. ${ }^{44}$

The cases also make it clear that once disclosure has been made to persons other than officials with an official interest in the records, the privilege will be deemed waived. Once waived in this manner, it may not again be interposed. Thus, in one case, an official complied with a lower court's order and disclosed the requested information. The appellate court held that, even if the original order had been in error and the documents privileged, once the information had been revealed and put in the record, the privilege was gone. ${ }^{45}$

In a limited number of cases involving law enforcement records, the courts have gone beyond the immediate scope of section 1881(5) and have used a concept of general public interest to prevent the disclosure of records that were not necessarily the product of confidential communications. Thus, in general, records, files, and documents dealing with the apprehension of violators of the laws are closed to public inspection. ${ }^{46}$ It has been recognized that law enforcement officers would be unduly handicapped in the performance of their duties if any person could go through any of their files.47 However, this exception to disclosure should, like others, be construed strictly and limited to records actually involving law enforcement that could not be revealed either without burdening law enforcement activities or revealing private affairs of citizens. Thus, as a rule, a record should not be kept from the public solely because it is found in the office of an agency whose activities include law enforcement. It is the nature of the particular records and the interests to be protected in its disclosure or nondisclosure that should be determinative.

40 Chronicle Publishing Co. v. Superior Court, 54 Cal, 2d 548, 568, 354 P.2d 637, 647, 7 Cal. Rptr. 109, 119 (1960).

41 See People v. Denne, 141 Cal. App. 2d 499, 512, 297 P.2d 451, 459 (1956).

42 Cf. Markwell v. Sykes, 173 Cal. App. 2d 642, 646-47, 343 P.2d 769, 772 (1959).

43 Chronicle Publishing Co. v. Superior Court, 54 Cal. 2d 548, 572, 354 P.2d 637, 649, 7 Cal. Rptr. 109, 121 (1960).

44 Ibid. But cf. Markwell v. Sykes, 173 Cal. App. 2d 642, 647, 343 P.2d 769, 772 (1959). Language in that case implies that under some circumstances (which the court does not specify) the public interest will not permit the exercise of discretion by an official. In such a case the court apparently would not allow disclosure.

45 Markwell v. Sykes, 173 Cal. App. 2d 642, 649-50, 343 P.2d 769, 774 (1959).

46 People v. Wilkins, 135 Cal. App. 2d 371, 377, 287 P.2d 555, 559 (1955). In criminal cases, however, the California courts have given defendants an increasingly broad riglit of inspection to find information relevant to their defenses. See Louisell, Criminal Discovery: Dilemma Real or Apparent?, 49 CALIF. L. REv. 56 (1961).

47 People v. Pearson, 111 Cal. App. 2d 9, 18, 244 P.2d 35, 43 (1952). 
In certain circumstances, records in government offices may fall within a privilege other than that of section 1881(5). Most often, this situation arises when a government agent communicates with a government attorney and seeks legal advice. Such a communication may be protected under the attorney-client privilege. ${ }^{48}$ Moreover, advice given by the attorney to the agency inay also be privileged and may be kept confidential if the agency feels it necessary. However, there are limits to the applicability of this privilege. Writings that would otherwise be open to public inspection as public records do not become privileged merely because they are turned over to the attorney, and the privilege is destroyed if third persons are allowed to see the documents. 49

\section{CONCLUSION}

To this point, the general inspection statutes, the statutes limiting access to specific records, and the governmental privilege have been discussed in general terms. The principles involved and their interrelationship may be illustrated by applying them to writings that present particular problems.

(1) Preliminary or investigative reports and data. Under the rule of the Coldwell case, reports and documents connected with public business are of legitimate interest to the public, and hence are open to inspection. However, portions of such documents that include confidential communications to public officers may be withheld. In addition, information relating to a private party's business affairs obtained from an examination of private books and papers is made confidential by certain statutes. 50

(2) Correspondence. Letters from private parties may be privileged as confidential communications. Moreover, if they deal with the private affairs of the writer, and are not connected with public matters, they would not come under the inspection statutes and, therefore, would not generally be open to the public. If, however, such letters contain information or comments relating to public affairs and are not confidential, they may be open to inspection.

Letters from the agency, on the other hand, sliould generally be open, particularly if they are of an official character, such as an opinion or statement of policy, or contain information concerming the activities of the agencies.

(3) Personnel Records. The question of whether government personnel records should be open to general inspection is a difficult one, particularly since many agencies apparently feel that they slould be confidential. ${ }^{51}$ With a few exceptions, there are no code sections covering the personnel records of the individual state agencies. However, there are a number of provisions in the Government Code relating to the State Personnel Board, restricting the availability of certain kinds of reports to that body. No information given to the board by any person is open to public inspection except under conditions prescribed by board rule.52 When pay data has been furnished on the understanding that the source remain confidential, the source is not open to the public. ${ }^{53}$ Applications for examinations and all

48 Holm v. Superior Court, 42 Cal. 2d 500, 267 P.2d 1025 (1954).

49 Coldwell v. Board of Public Works, 187 Cal. 510, 521-22, 202 Pac. 879, 884 (1921).

50 E.g., CaL. Gov's Code $\$ 11183$.

51 Cal. Senate Special Committee on Governmental Administration, Public Records Survey, 1 Appendx to tere Journat of the Senate 10, 78, 79, Cal. Leg., Reg. (Gen.) Sess. (1955). 62 CAL. Gov'T CODE $\$ 18573$.

68 Ibid. 
other examination materials are confidential and open to inspection only as provided by board rule..$^{54}$ Certain appeals by aggrieved employees are secret. ${ }^{55}$ Performance reports on employees are open to the employee affected; the board may decide the extent to which they will be open to public inspection..$^{68}$

It is evident that the purpose of these sections-tlie prevention of the disclosure of the private affairs of state employees-would be defeated if the same information leeld secret by the personnel board were open to inspection when in the possession of other state agencies. Therefore, in general, information covered by the above statutes and kept confidential by the board should also be withheld by other state agencies. ${ }^{57}$ However, if the board, acting under the discretion given it by some of the sections, decides to make certain information public, then there would be no point in other agencies keeping it confidential. In addition, communications from third parties coming within the scope of section 1881(5) may be kept confidential..$^{58}$ However, the legitimate interest of the public in being informed of the conduct of its employees must be given some recognition. Therefore, other personnel records that do not come within the specific terms of one of the code sections should be open to inspection, unless the information contained therein is of a completely personal nature in which there could be no public interest.

In summation, it may be said that documents and records in the custody of a public officer should be presumed open to inspection by the public. The test to be applied in any situation is whether the document is connected in some way with the conduct of public affairs, so that there is a legitimate public interest in it. If, however, it deals with the private affairs of an individual and there is no general public need to know about such affairs, the document does not come within the scope of the general inspection statutes. Indeed, the majority of the statutes expressly providing that certain documents be kept secret are designed to protect the privacy of an individual when he must supply information to the government. In addition, section 1881(5) of the Code of Civil Procedure removes from inspection confidential communications to the government in order to ensure a free flow of information necessary for the effective conduct of public business.

Charles S. Ralston

54 CAI. Gov't CoDE $\$ 18934$.

55 CaI. Gov't Code \$ 18952.

58 CaL. Gov'T Code $\$ 19302$.

57 The same would hold true for information covered by other code sections, e.g., CaL. Educatron Code \$ 14026.

58 See Colnon v. Orr, 71 Cal. 43, 11 Pac. 814 (1886). 